\title{
The Discovery of the Great Wall of Jordan, Southern Levant
}

\author{
Mohammed Waheeb \\ Queen Rania College of Heritage \& Tourism, Hashemite University, Amman, Jordan \\ Email address: \\ mwaheeb@hu.edu.jo

\section{To cite this article:} \\ Mohammed Waheeb. The Discovery of the Great Wall of Jordan, Southern Levant. International Journal of Archaeology. \\ Vol. 9, No. 1, 2021, pp. 1-9. doi: 10.11648/j.ija.20210901.11
}

Received: December 3, 2020; Accepted: December 28, 2020; Published: January 12, 2021

\begin{abstract}
Great wall of Jordan also known as Khatt Shebib is a unique ancient wall situated in Southern Jordan near Maan City. The remains of the wall which includes towers, barracks, rooms ...etc. are $150 \mathrm{~km}$ long from south to north, making it the longest linear archaeological site in southern Levant \&in Jordan. The archaeological remains of the wall were first identified by British experts, the discovery was unveiled in 1948, then it was documented by air photographing in 1982, the Department of Antiquities explored it in 1992, with survey, excavations, \& documentation continued to the present day. Located in the south of the Kingdom, the wall is the world's second longest after the China Wall, as it spans a distance of approximately 150 kilometers approximately, making it the region's longest structure. Known locally as Hableh or Khatt Shebib, the wall stretches northwards from Ras Al Naqab in Maan Governorate extending to the Wadi Al Hasa area of Tafileh Governorate, A Jordanian team of archaeologists and experts imitated a field project in 1992-1996, and 2020in order to document the nearby remains of the wall, where comprehensive survey and excavations urgently needed in several significant sites along the wall sides. The field study concluded in revealing significant architectural structures built directly adjacent to the wall, also focused on the importance of the wall to be an attractive point for tourism in South Jordan. The date of the wall's construction clearly refers to Nabataean Period.
\end{abstract}

Keywords: Archaeology, Wall, Cultural Heritage, Roman-nabataean, Excavations

\section{Introduction}

Known locally as Khatt Shebib, Located in the south of the Kingdom, representing the region's longest structure not only in Jordan, but in the whole of southern Levant. Jordan's own "great wall" the remains of the wall are ranged approximately between 140-150 km long, making it the longest linear archaeological site in Jordan and the secondlongest structure built by humans in the world next to the Great Wall of China, according to the field studies and investigations results this wall represent a major step toward civilizations development in the ancient world.

Located in the south of the Kingdom, making it the region's longest structure not only in Jordan but in the whole of southern Levant. It stretches northwards from Ras $\mathrm{Al}$ Naqab in Maan Governorate through Shobak to the Wadi Al Hasa area of Tafileh Governorate.

Currently, field studies ${ }^{1}$ are being conducted to ascertain

1 A team composed of Prof Mohed Waheeb Archaeologist, Dr Abed Aziz Anthropologist, Dr Jumanah Dweikat Tourism expert, Abd Raheem Arjan Media the wall's purpose, with another hypothesis suggesting that it could have linked various trade routes in the region.

Archaeologists, anthropologists and tourism experts still authenticating the area's role in ancient times, especially focusing on the wall's ancient sites.

\section{Thewall (Khat Shabeeb)}

The local community in Ras an-Naqab villages informed the team of the work during their field operation in 1992 that this wall named after Shabeeb, and well known as Khat Shabeeb (khat means in Arabic: line) so the name derived from our Arabic language while the term 'Khatt' or Khatt Shabeeb was directly translates to 'line 'in English language. The resemblance or similarities between the wall and the line pushed the local people or villagers and their ancestors to adopt this name since centuries ago, which is still used up till nowadays continuously. Another name for the wall is Hableh

Expert \& Photographer, Munawer Shakhatreh Manager \& Laison Officer, Jumaa Khateeb Tourism Expert, Mohed Hammad and Burhan Arab Tour Guides. 
used Near Shobek area, also stems from Arabic, the term Hableh derived from rope (similarity between shape of the rope and shape of line) lastly translated in English as Khat.

The question raised here, who is Shabeeb the Owner of the wall? The legend or narrative say that Ameir Shabeeb or Prince conquest the area from south Maan toward north trying to capture the whole area of Jordan to be ruled by his authority as a strong leader in the Medieval Ages. During his struggle to the north, his horse was fell down causing suddenly death to Shabeeb between Maan and Zerqa near Amman [20].

There are three places could be ascribed to this Shabeeb in Jordan those are as follow:

First: Qaser Shabeeb (Shabeeb Palace) in Zerqa District north of Amman City Capital of Jordan, the current remains of the palace consist of two stories provided with arrow slits, a courtyard and large water reservoir, this palace ascribed to prince Shabeeb according to several travelers who visited this site through history, among of them, [4-6, 30, 34, 47], the date of the place ranged from Roman period - Ottoman. The scholars concluded that the structure could be a fort rather than a palace, while the Ameir Shabeeb either al-Tubaai of Hemyri, Uqeily, Meqdadi, or Mehdawi is still needs more investigations in the history to be settled down. [46] This made the matter of date the palace so confused, and possibly the date ranged broadly between $10^{\text {th }}-18^{\text {th }}$ centuryAD.

Second: Khat Shabeeb near Amman, which is a stretch of land on the western edge of the plain (without a wall) or any architecture visible on the surface of ground, extending from west Amman,(wady sir) and Iraq Al-Ameir village to Naur village and ended in Hesban village, The ancestors of the local inhabitants refers to shabeeb as the owner of these villages, locality, and the whole land and territory east of this unseen line (khat) belong to him, while his base and living place was been in the famous palace called Qaser Shabeeb in Zerqa as mentioned above. [20]

Third: Khat Shbeeb, south Jordan, which was identified in 1948 and still subjected to field assessment by the author and his team Figure 1.

\subsection{Geology}

The wall (Khat Shebib) runs mainly though the southern Jordan Badiyeh rather than desert. The landscape of this expansive desert consists primarily of sand dunes and Rocket Mountain.

"Cambrian -Silurian sedimentary succession exposed east central Sinai is described, and subdivided into three formations: Sarabit al-Khadim at base, abu Hamata in the middle, and the adedia on top, the newly described Ras alNaqab Member yielded Ordovician fossils of the sublittoral khracies. These rock units are identical to their counterparts in west-central Sinai and can be correlated.

With those exposed in southern Palestine, but are far much less thick and poorer in fossils tan equivalent strata in southern Jordan, and north western Saudi Arabia". [27]

Furthermore, Khatt Shebib reflects the geology of its setting, as the rocks used in its construction vary according to the geological framework of the area. (Kora: 1991) see Figure 2.

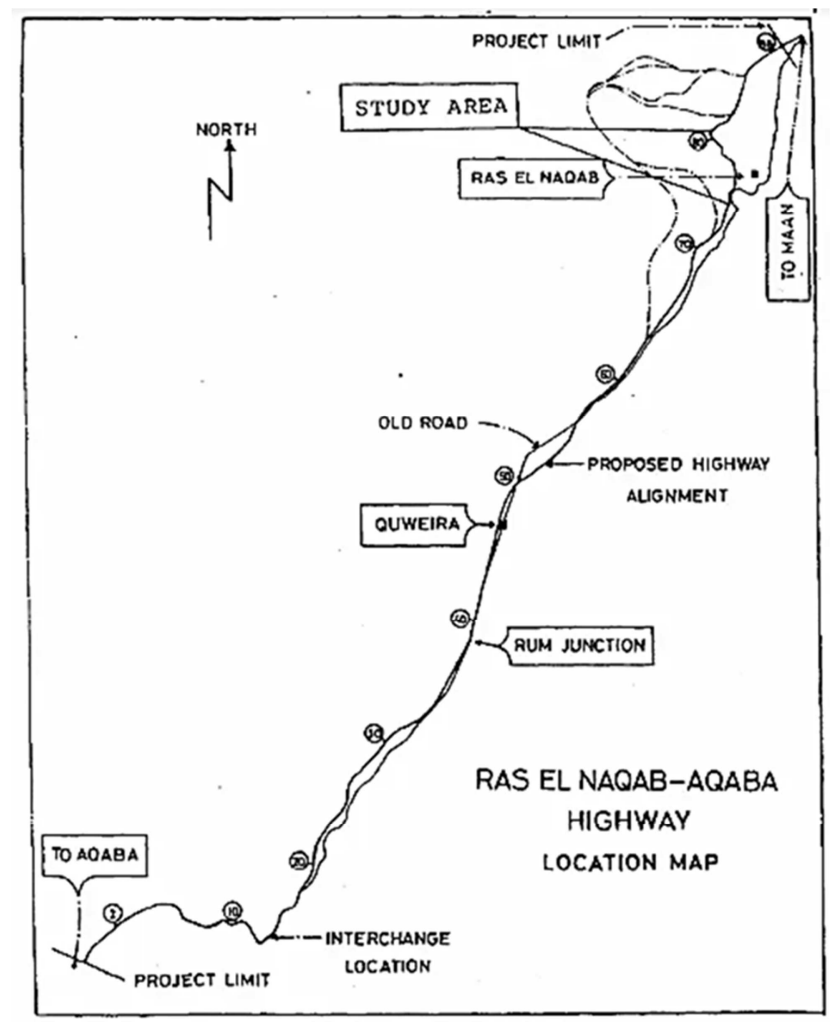

Figure 1. Location map of the Ras an-Naqab area in Jordan.

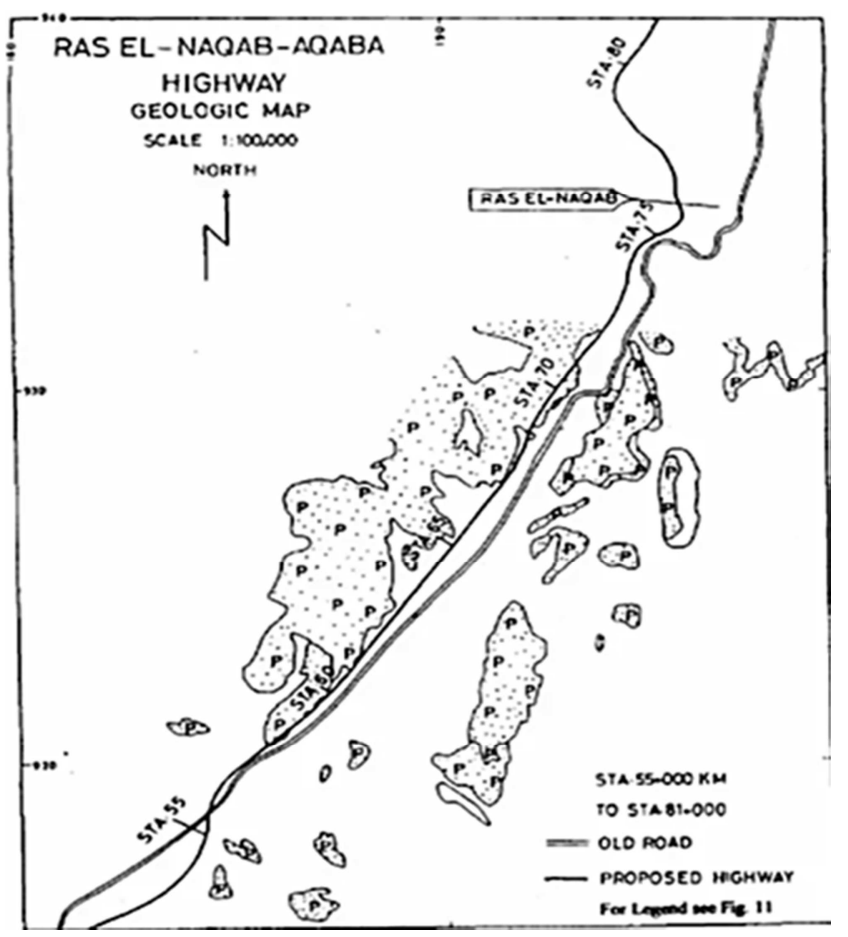

Figure 2. Geological map of the study area in Ras an-Naqab.

Field Work

Field work in Ras an-Naqab area initiated in 1992-93by Dept. of Antiquities of Jordan and continued during 1994-96 
then, 2019-2020included survey, excavations, documentation and assessment for Environmental Impact Assessment reports (EIAR). While documentation of tangible and intangible heritage continued in the area during the past years, the current works resulted in discovering of several major, medium, and minor sites, among of them prehistoric sites, agricultural villages, watchtowers, cairns, water installations, and ancient roads.

One of these major discoveries is the longest wall in the middle east, so called by local community as Khatt Shabeeb, the wall was subjected to field assessment and evaluation during seasons of 1992 till 1996, from the starting point in southern Maan area specifically Ras Naqab near Khirbet Daouk \& Shdyeid. The wall continued northward to Umm Quseir \& Khirbet Mureigha passing west Maan reaching north Wadi Hasa area in Tafeileh District Figure 3.

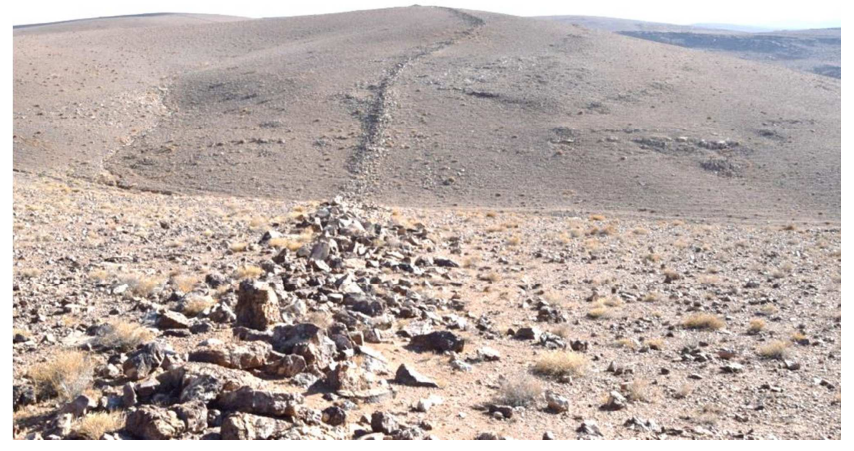

Figure 3. Section of the wall remains in Ras an-Naqab Area (Waheeb: 2020).

The Wall was placed slightly inRas an-Naqabnorth of the existing lower area of Dabbat Hanut and Qaa Al-Naqab between the old road of Ras an-Naqb (English Road) to the west, and the high mountains to the east. Its line was carefully chosen to make best use of the topography, and extended to north- south direction.

\subsection{Objectives}

The main objective of this work is to shed light on the importance of the recovered architectural remains of the wall\& the surrounding zone in order to link the wall with other nearby newly discovered remains along the route from Maan to Hasa where major sites were found during the process of survey and excavations since 1992 till 1996 and continued now days.

Also aims to match the results of previous conducted work of systematic survey\& excavations in Ras Naqab area, with the newly gained data for analysis and comparative studies.

Field work designed to conclude contribute in revealing several branches connected to the main wall noticed in previous seasons, in addition to that a major structures will be exposed which consists of either isolated or connected rooms and circular structures as well as other associated facilities on both alignment of the route.

The discovery of the wall traces, foundations, associated buildings \&branches considered as a progress step toward identification of lost parts of this great wall and will introduce new archaeological evidences such as the function and date of these remains.

\subsection{Previous Studies}

The area subjected to preliminary assessment before initiating our field project during 1992-1996 seasons and 2019-2020 seasons.

Due to its magnitude, in 1948 the site garnered the attention of British Alec Kirk bride, who wrote preliminary observations on the wall, \&first identified the wall, argue that the Khatt Shebib was used for military and defense purposes $[25,26]$.

Another organization involved in this process of researching the Khatt Shebib is the 'Aerial Photographic Archive for Archaeology in the Middle East' "these projects photograph and survey the ancient wall from above and on the ground. Using this they study the wall through methods such as comparing the modern remains to historical imagery and maps mainly from 1948 and in 1982. These aerial archaeological projects headed by Kennedy have produced substantial documentation on the Khatt Shebib, contributing to the understanding of the wall's geographical landscape, structure and features" [23], but despite his achievements Kennedy reduces the positive expectations of the wall as a significant discovery in southern Jordan [23].

The 'Aqaba-Ma'an Archaeological and Epigraphic Survey (AMAES), directed by the late William (Bill) Jobling of the University of Sydney from 1980-1990, "was the first official comprehensive survey of the ancient remains found in the Hisma/WadiRamm desert of southern Wadi Ramm desert of southern Jordan".. While the Hisma's most prominent archaeological and epigraphic sites had been documented by earlier scholars, most notably George Horsfield, R. Savignac, G. Lankester Harding, Diana Kirkbride, [18, 32, 33]. The AMAES aimed to fully explore the entirety of the region's vast network of sweeping valleys, towering rock faces, and sprawling boulder fields. In all, the survey explored an area of more than 2,500 sq. km, extending from the Red Sea port city of 'Aqaba in the west to the desert outpost of Mudawwara in the east, and from the well-watered Ma'an plateau and Ras an-Naqab escarpment in the north to Jordan's desert border with Saudi Arabia in the south.. [22] See also [31].

Field survey and excavations under direct supervision of the author, initiated a campaign during 1992, and focused on Ras an-Naqab and surrounding area see [3, 19, 38, 40-49].

Several sites were registered during our field survey among of them, Kh Daouk, Umm Quseir, KhShdeid. etc. Those sites situated very close to the wall on both sides. The spring in Ras an-Naqab at 'Ayn Jammam is easily recognizable as one drives north on the highway from 'Aqaba to Ma'an, for the vegetation it stands out in stark contrast to the steeparid hillside around it. It is not surprising, then, that archaeologists have been aware of the site for some time e.g. $[16,17,22,43]$, but it was not until the mid1980s that H. Gebel during 1993 was able to determine the significance of the settlement. The site consists of two 
components: one is a large structure with artifacts that indicate a Nabatean -Late Roman-Early Byzantine occupation [39]. The second component is Neolithic, including LPPNB and Pottery Neolithic occupations [15]. Claims of a PPNC occupation [43]. have not been verified by lithics analysis. Two radiocarbon samples yielded dates of $8,520 \pm 190$ uncalbp $(9,551 \pm 253$ calBP; and $8,030 \pm 120$ uncalbp $(8,899 \pm 186$ calBP) [3]. Highway construction plans threatened to damage the site severely, so the Cultural Resource Management department of the Department of Antiquities undertook two seasons of rescue excavations in 1995 and 1996, brief reports have appeared on the excavation as well as unpublished MA thesis [39, 10, 11, 43, 35].

Another study entitled (A first radiometric chronology for the Khatt Shebib megalithic structure in Jordan using the luminescence dating of rock surfaces) concluded with a Persian date of the wall [24].

A researcher from King Hussein University in Maan Fawzi Abu Daneh refers to this wall as (site no 62) among other sites found in west Maan -Udhruh [2].

The leading method of studying the wall is aerial archaeology and multiple international archaeological organization have established projects in order to understand and discover more about the wall [23].

\section{Function}

The Khatt Shebib has gained increasing attention amongst archaeologists.

Kirkbride first identified the wall, argue that the wall Khatt Shebib was used for military and defense purposes.

However, as more has been discovered about the building and structure of the Khatt Shebib, some contemporary archaeologists have dismissed this theory, suggesting that the wall is somewhat low, 2 meter high, to have been used as a successful defense mechanism. Instead it is believed that the Khatt Shebib served as a border, indicating separate areas and divisions of land. [23]. unlike its east-Asian counterpart, however, it does not seem to have been used for fortification, leaving its purpose an item of speculation for archaeologists and historians

"This border acted as a means of restricting the access of nomadic populations to settled and farmed regions" [28].

Some evidence seems to show that the wall was used for agricultural purposes, as it was no more than a 2 meter high, that the inhabitants of the area, especially to the west, were known to be farmers. [1].

Historians believe the original plan was to build a wall of stone as a strong material to defend external threats. The wall would feature a guarded gate for the western areas.

The purpose possibly was to control movement across the frontier and to counter low-intensity threats. There was no intention of fighting from the wall top; the units based on the wall were trained and equipped to encounter the enemy in the open.

Do the ruins of this wall tell the same interpretation as scholars did? On the other hand, there has been no wavering about the fact that the wall was been used as a protection and somewhat limited defensive purposes. So far no signs of military usage in recent times have been discovered. In spite of it, the conclusions, is permissible that there was an important and distinguished wall in southern Jordan. Whether this wall/ Khatt Shebib was used for military purposes or rather the ancient wall served as a border, is a matter of debate among the scholars, the size of damage affected the upper courses of the wall and shortage of field excavations of the wall itself or in the buildings found on both sides, forced us to limit our expectations, since lack of any support either from inscriptions or architectural analysis and comparative studies see [19]. Most of the found inscriptions found during field operations dated to Safaitic or Thamudic settlements in the area (Figure 4).

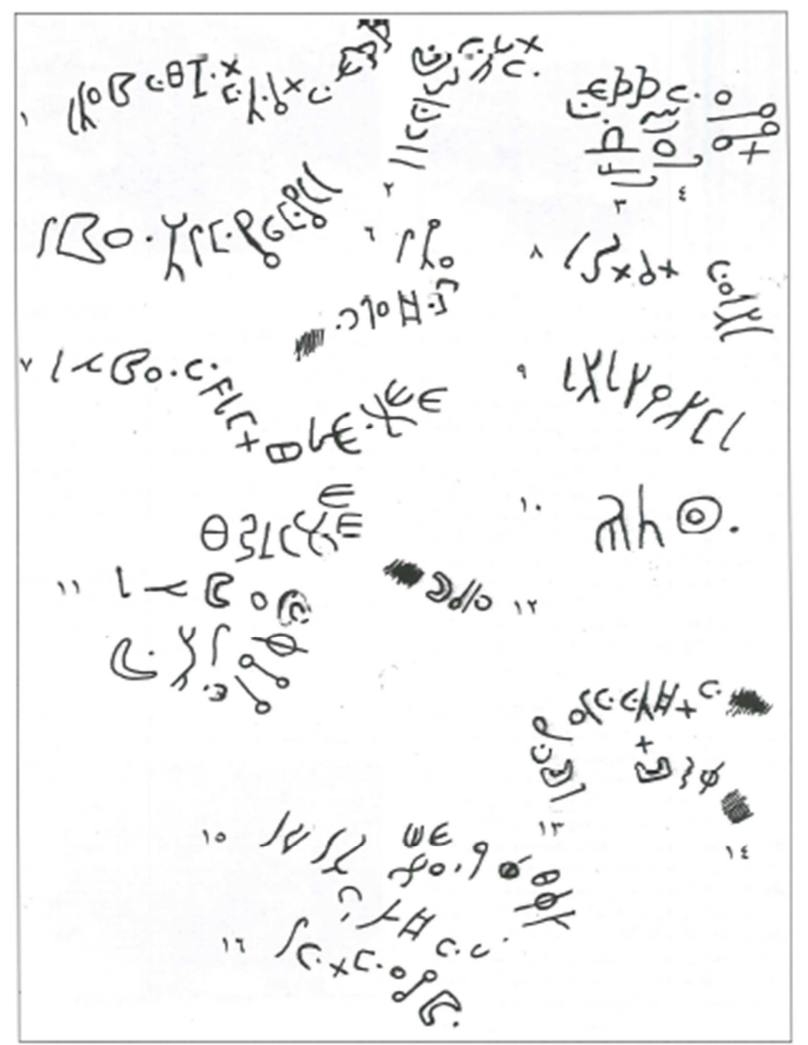

Figure 4. Inscriptions found near the Great Wall (Khat Shabeeb) during the field survey (Harahsheh \& Waheeb: 2003).

Either we must adopt special attitude or follow the previous assumptions which lead us to uncertainty of the function of the wall.

During the Nabataean period, however, there were many kingdoms in the region, so the wall/ Khatt Shebib may have marked a boundary between different kingdoms. It is also one of the earliest records of the building of a border wall, and has may influenced modern border structures today. The wall began as a series of independently constructed walls as long ago as the EBA3000 century BC, Fuji directed excavations by Japanese mission in Jafer, Burma, and surrounding area, he is the second after our operations who initiated field work in the wall and nearby structures, lastly 
the excavated area of the wall dated to the first half of third millennium EB1A, named as Klines, HBKL[12-14].

This term $(K$, line) created by Fuji derived from Aharonis designation for a unique structure that was confirmed for the first time in the Negev High lands in the latter half at 1950 [9].

Over time, it's logical to assume that these separated parts became connected into a single vast wall during later periods, such as the Islamic Period. The wall's major function was not only militaristic purpose to defend Nabatean against the multitude of invaders that plagued the borderlands primarily the nomadic people [25]. But the walls provided other economic and social benefits for Nabatean, allowing the Nabateans to enforce economic duties along the Incense Route as well as decrease the number of immigrants from Arabian Desert.[21] As a means of maintaining control over citizens of Nabatean who settled in (Ras Naqab, on the western side of the wall) and their trade, the Great Wall was quite successful. However, the wall did not contribute effectively to keep enemies \&invaders out entirely. The Roman army under direct control of Emperor Trajan invades and takes territory across the north near wadi Hasa where the wall ended. Though this wall has never been altogether destroyed, still standing since the Bronze Age through Iron, Hellenistic, Roman, Byzantine, and Islamic Age, its maintenance was, and is, such a colossal undertaking that large sections of it have fallen into disrepair over time due to natural and human factors.

\section{Methods of Construction}

"As local archaeologists, we began to turn our focus to full implementation in 1992 by bringing together artifacts and features that we collected during excavation work,"

The wall is predominately constructed from available rocks scattered on the surface of the ground and used different kinds of rocks such as limestone, flint, sedimentary of two rows and filled the space between them with smaller stones\& chunks, while it is not dressed chunks were used on the external both surfaces to fix the stones regularly, large stones or boulders were used as foundations for the wall, while other medium stones used in the upper courses.

Other organic or non-organic materials not ruled out during filed investigations, test soundings now designed to get systematic sand samples to be analyzed as soon as possible. However, due to the significant length of the wall through mountains, valleys, slopes and plain areas, these materials mainly rocks differ along the span of the wall as the availability of resources varied in each location. See (Figure 5).

The original plan was to construct a stone wall $1-1,50 \mathrm{M}$ wide or more in some cases, and at least 1,50-2M high and may more than of 2 meters due to the level of ground for the sector of Ras Naqab highland area where several structures were found attached to the wall.

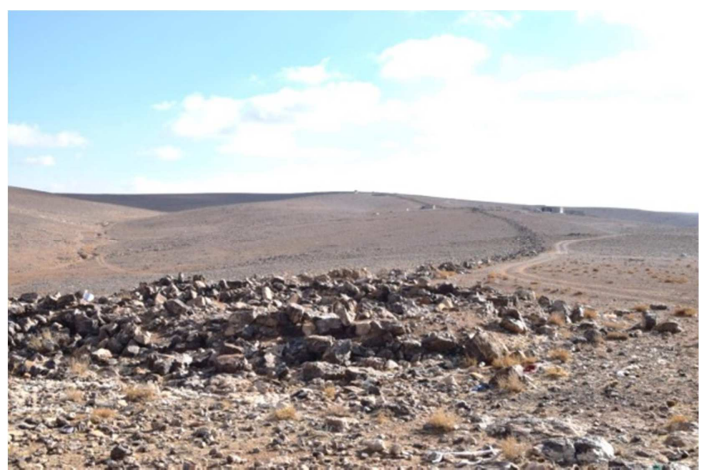

Figure 5. Remains of al- Hablh Building (UmmQuseir) constructed mainly of flint stones attached to the wall in Ras an-Naqab Area. (Waheeb: 2020).

At the time of its construction during the Nabatean period, the wall was approximately taller than a 2 meter with associated structures, and later after continuous fell down possibly becomes one and half high. Due to different types of direct and indirect threats to the integrity of the wall, including climatic change issue and growing population pressures, the wall is significantly now smaller, the existed height is less than one meter, these measurements restricted only to Ras an-Naqab area.

Given the wall's length, it seems that the construction period had phases, which implies that various cultures left behind proof of their existence through its architecture,", noting that archaeological evidence from the wall suggests that it was mainly built during the Nabataean period (312 BC-106AD).

At somewhat regular distance there was a structure (towers, barrack-blocks or buttresses) either square or circular shape, and at every mile but not regular a village site containing a gate through the wall, presumably supported by a tower (Figure 6).

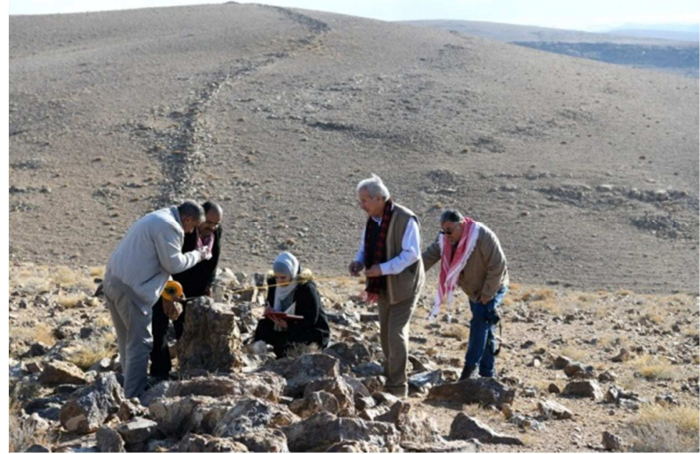

Figure 6. Field work assessment of the wall remains on a sloppy area in Ras an-Naqab (Arjan: 2020).

Most of these towers are affected by human and natural factors and now in ruins. Archaeologists and historians have only been able to hypothesize the ways or the methods in which they were used in previous times. It has been suggested or concluded that these structures (the wall and surrounding buildings) could have been designed as watchtowers, or shelters used for protection from deserts and storms or storage means for food. Many archaeologists and 
experts agree that the towers would never have been used for limited function such as military purposes since they are relatively small, measuring about two to four meters in diameter. Through examining these towers, archaeologists, historians, early architecture experts, and anthropologists have been able to document, and discover more about the construction methods, the lively hood sand lifestyle of the Ras an Naqab builders or people of the wall. (Figure 7).

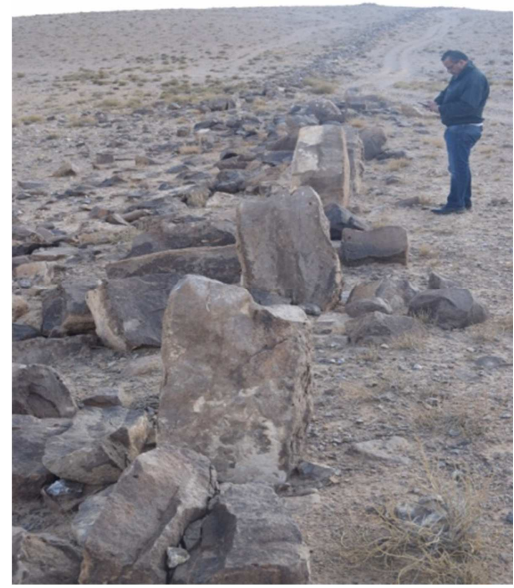

Figure 7. Upright stones still standing showing the method of building the wall between Kh. Daouk and UmmQuseir.
Extensive archaeological research and discoveries conducted in Ras an-Naqab close to the starting point of the wall revealed strong evidences to date the construction of the wall.

Earlier attempts by surface investigations including systematic survey, test trenches, limited excavations or even comprehensive excavations, concluded that the wall was built during Bronze Age3200-1200BC, IronAge1200-850BC, and Persian539BC to 332BC, Nabatean Period 332 BC-106AD and medieval period $10^{\text {th }}$ - Ottoman Period.

The major scientific archaeological project In Ras anNaqab area included field survey and comprehensive excavations along the western areas of the wall shed more light on the process of chronology of the wall's construction. Through field investigations the stratified layers in sites of Al-Hiyyed, (Shami, 1997) AinJamma2, Abu Nusur, Dabet Hanut $1 / 2 / 3$ and test trenches here and there in Tasan, Kasmiyeh, determined that the excavated and explored sites had been rooted from Paleolithic to Late Ottoman approximately500,000BC -1918AD.

Most of the buildings and recovered datable materials dated to the Nabatean -Roman periods (Classical) also referred to as the Byzantine. se Table 1.

Table 1. Major Archaeological sites identified in Ras an-Naqab near Jordan's Wall during Field operation 1992-1997 (Waheeb: 2020).

\begin{tabular}{|c|c|c|c|}
\hline No & Site Name & Major Periods & Note \\
\hline 1 & Al-Daouk & Nabatean & Surveyed / Not excavated \\
\hline 2 & Shdeyd & Iron II, Nabatean & Surveyed / Not excavated \\
\hline 3 & East Fweileh & Nabatean/Classical & Surveyed / Not excavate \\
\hline 5 & Abu Lussun & Nabatean/Classical & Surveyed / Not excavated \\
\hline 6 & Umm Quseir & Nabatean/UD & Surveyed / Not excavated \\
\hline 7 & Ain Jammam 1 & Neolithic/Nabatean & Surveyed + excavated \\
\hline 9 & AL Hiyyieed & Nabatean / Classical & Surveyed + excavated \\
\hline 10 & Tasan & Nabatean / Classical & Surveyed + excavated \\
\hline 11 & DabbetHanut 1 & Nabatean / Classical & Surveyed + excavated \\
\hline 12 & DabbetHanut 2 & Nabatean / Classical & Surveyed + excavated \\
\hline 13 & DabbetHanut 3 & Nabatean / Classical & Surveyed + excavated \\
\hline 14 & Al-Muregha & Nabatean / Classical & Surveyed + Not excavated \\
\hline
\end{tabular}

This scientific survey and excavations has provided and supported the first dependable or reliable dates of Ras anNaqab buildings, and revealed the positives of using result $s$ of systematic survey and excavations in the interpretation process of several sites found very close to the wall.

Along side this scientific field research and documentation the team of the archaeologists have discovered significant Nabatean sites such as abu Nsur village \& Dabbat Hanut structures, Nabatean water systems, watch towers of different types and shapes, ceramic artifacts, such as pottery sherds, at sites along and very close by the wall.

The number of these findings is large enough to rely onto indicate a period of construction or use of the wall to be contemporary by the establishment of these village sands its mainly from the $3 \mathrm{edBC}-7^{\text {th }} \mathrm{AD}$; however, this clear and significant archaeological evidence is believed by archaeologists and experts to be dated since the Early to Late Nabatean, period, and Early to Late Roman \&Early to Late Byzantine Period [38, 39, 10] Figure 8.

Although we have now after a systematic excavations scientific, and archaeological evidence, that dates the building of Abu Nsur, Dabat Hanut in the Early Nabatean Ages.

Preliminary assessment of the timeframe of wall's construction is ranged from the third BC to the seventh AD.

Most of the wall experts, and archaeologists who worked on this wall agreed on that the wall (Great wall- Khatt Shebib) was not built in a short or limited period of time, rather, construction took place over prolonged period of time as sections were added (or phasea) and joined together, for example the results of Japanese mission assured this theory which dated the wall back to EBA3000 century BC [13]. 
This may presents a challenge to experts and scholars at the beginning of the assessment and evaluation work who are aiming to determine the exact date of the wall construction.

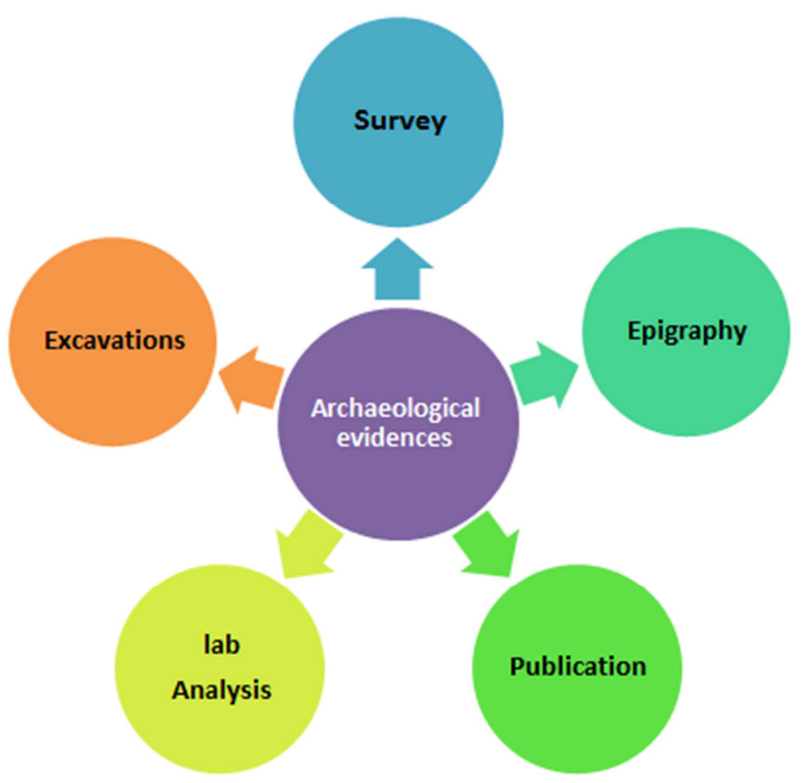

Figure 8. Archaeological evidences used for dating the wall, khatt shabeeb (Waheeb: 2020).

The date of the wall, Khatt Shebib's constructionis around to settle down in the period of Nabatean Kingdom, however, it has been widely debated by archaeologists and nonarchaeologists. This is evident as some experts or archaeologists argue or insist on that the wall and other associated structures were built during the Nabatean Period, whilst others argue it was possibly constructed during the Hellenistic or Persian era.

\section{Discussion}

Jordan's Wall appears to have continued in this form into the late 2 nd century. A major war took place shortly after AD 106, when 'the Romans crossed the Wall which ended in destroying the whole defensive system of the Nabataea's. We know no details of the subsequent fighting in the area of the wall, but it probably led to changes to the wall, including the abandonment of many parts and the village sites and possibly redeployment of the army and the villagers as well as building the major Roman Road through Ras an -Naqab area.

In the late 2 nd or early 3 rd century, new road constructed to the west of the wall which is called Via Nova Triana, so that the wall could continue to be used by local farmers as borders or protection wall against savage animals attacks their farms and houses, while a minor rather major repair to the Wall itself took place.

Similar to other walls and several archaeological structures in the Middle East, the great wall of Jordan -Khatt Shebib faces different types of threats to the structures 'integrity and sustainability. These types of threats include re-purposing the site and nearby structures for agricultural means and the destruction of the ancient ruins during conflict, mining activities or construction as populations grow and villages or cities expand.

Natural factors like erosion, and human role represented in robbery activities, looting are also major direct threats to the wall, and associated structures integrity, which is already evident and clearly visible along various parts of the Great Wall where only a few original rocks remain and still standing.

In the years that followed, Nabateans, the wall became a quarry for the stone to build villages, farms and houses along its line, until the conservation movement in the 18th and 19th centuries after establishing the Dept. of Antiquities 1921 -23 put a stop to that. It was only from the mid-19th century onwards that early archaeologists and historians such as Kirkbride, Lankester Harding, David Kennedy, Fuji, and other Jordanian scholars began to study Jordan's great wall and sought to protect its still magnificent remains.

Over the centuries many sections of the wall have suffered damage caused by roads traversing it, and by the plunder of its stones to build nearby either Roman- Byzantine Villages or the new Roman Road and other structures. However, the remaining foundations and forts could attract tourists from throughout the world.

It is urgent to prevent area farmers and project owners from removing the stones of the original wall to build private projects and/or construct dirt or paved roads, buying up the surrounding land and establishing a corridor of at least30meters is a must in this phase as well as to fund restoration work on this wall.

Jordan's wall should be listed on tentative or nomination UNESCO World Heritage site. It remains unguarded, meaning tourists visiting the site have unfettered access, despite concerns over damage.

More recently, when two workshops held in Amman and Maan in winter of 2020, Jordan's Wall were adopted by NGOS as a touristic route and considered as an excited structure not only in Jordan, but in Southern Levant. Figure 9.

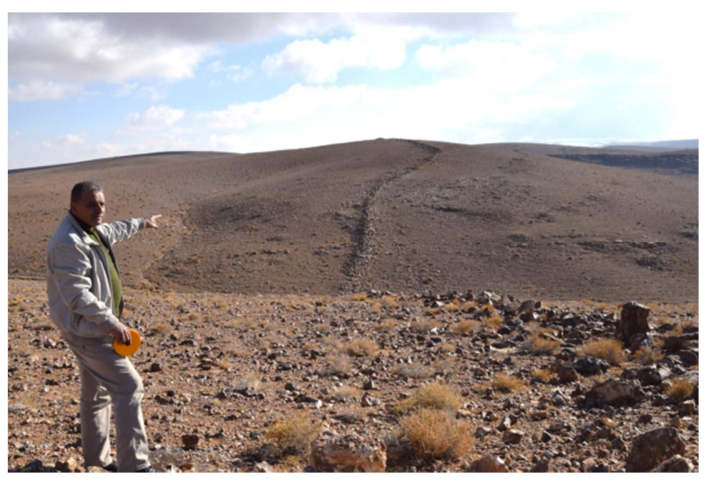

Figure 9. Team member Munawer Shakhatreh pointed to the wall extension in Ras An-Naqab (Waheeb: 2020).

Jordan's Wall walk remains will become a popular tourist activity, and the wall was included in The Guardian's "Where to Go in 2017" list. A visitor's center explaining the historic significance of the site is reportedly in the works. 


\section{Tourism Development}

An expedition to access the wall's most significant features was organized during the past 6 months to gain more information about the current situation of the wall and to evaluate future needs for preservation and consolidation.

In 1996, the team of the archaeologists formed a partnership with the Military Culture Department, which resulted in the creation of a museum at Prince Hashem Bin Al Hussein School in Ras Al Naqab that displays a number of artifacts and items discovered in the area of the wall over the years.

Really what attract tourism to the area of the wall are the presence of the museum, the remains of 'great wall of Jordan', the discovered antiquities and sites, and Al Sharat Mountain range as well as the remains of the trade routes in the area.

The NGO, s in Ras an-Naqab area and the tourism sector in Jordan held together several workshops during 2015-2020 discuss the significance of the wall and the surrounding major sites, aiming to define its role in improving tourism.

Endeavors are being made to study the area with the aim of transforming it into a tourist destination after carrying out the proper maintenance.

\section{Conclusions}

The results of field studies described above may help explain how the Nabataeans civilization flourished in Southern Jordan and how the Nabataeans were able to move from the Jordanian highlands into the semi desert areas and practice agriculture based on water harvesting and how they protect and defend their territory. They may help explain, at least in part, the proliferation of Nabataen, Roman and Byzantine settlements in areas that are today virtually devoid of human habitation.

It must also be pointed out that influences other than Nabateans may have been responsible for the establishment of settlements during the Pre-Nabataean, Roman and Byzantine periods. Nevertheless, the major discovered structures and artifacts as noted above for the periods under discussion must be seriously considered in an attempt to understand settlement patterns in the Ras an-Naqab area in southern part of the country for the periods of interest here [29].

Finally, Jordan Great Wall is longer than Hadrian's Wall which continuous Roman defensive long wall that guarded and protected the north western frontier of the province of England from external threats and barbarian invaders. The wall started and extended from the place called coast to coast across the width of northern Britain; it ran around 73 miles which equal to $(118 \mathrm{~km})$ from Wall send (Segedunum)on the River Tyne in the east to Bowness on the Sol way Firth in the west.

Except Chinas wall Jordan's wall is longer than other walls in the world among of them the wall of India. After Europe India comes next in line for building great walls. Surprisingly unpopular, Kumbalgarh Fort has a $36 \mathrm{~km}$ wall surrounding it.
A massive, continuous wall, built around the 15 th century is out there in open sight and we still don't talk about it.

The unique remains of Jordan's wall deserves not only preservation and conservation but some degree of aesthetically and archaeologically appropriate development so that it can become again, like the Chinese and Europe walls, a focal point in the southern Levant. The proposed work needs not only a comprehensive conservation and management plans for the discovered parts, but also a detailed interpretation schemes that describe the specialty of the wall and its features within its current landscape.

\section{References}

[1] Abu Jaber, 1989, R Pioneer settlement over the Jordan, SHAJ, $5,737-744$.

[2] Abu Daneh, F, 2004, the archaeological survey of the region of Udhruh, 2003, Preliminary Report. ADAJ, 48, 51-69.

[3] Bisheh, G., Farajat, S., Palmumbo, G., Waheeb, M., 1993, "Archaeological rescue survey of the Ras An-Naqab Aqaba Highway Alignment 1992”, ADAJ, 37, 119-131.

[4] Burkhardt, j, 1882, Travel in Syria. And the holy land, London.

[5] Butler, H, 1909, Ancient architecture in Syria, southern Syria, Brill, Lyden.

[6] Doughty, C, 1926, Travel in Arabia Desert, London.

[7] Eadie, J., 1984, "Mumayama1983: the regional survey", ADAJ 23, 211-224.

[8] EAMENA, the Aerial Archaeology in Jordan Project. EAMENA. 2016-12-05. Retrieved 2019-05-11.

[9] Evernari, M, Aharoni, Y, Shannan, L, \& Tadmor, N, 1958, The Ancient Desert Agriculture of the Negev,: III, Early beginning, IEJ, 8, 231-268.

[10] Fino, N 1996, Ain Jammam, Archaeological study, Jordan University, Unpublished MA thesis, Dept. of Archaeology.

[11] Fino, N 2004, Evidence of Settlement Organization at Ain Jammam, Symposium, Central settlements in Neolithic Jordan; 1997; Wadi Musa, Jordanian, Studies In Early Near Eastern Production, 5; 105-112.

[12] Frye, David (2018). Walls: a history of civilization in blood and brick. London: Faber \& Faber. ISBN 9781501172700. OCLC 1012798550.

[13] Fuji, S, 2002, Qa abu Tulyha west, an interim report of the fifth season, ADAJ, 46, 15-39.

[14] Fuji, S, 2004, Harrat Burma cairn field, wadi Burma south, cist enclosure and kite site, and Harrat al Sayyiya K lines, A preliminary report of 2003 summer season of the Jafer Basin, prehistoric project, phase 2, ADAJ, 48, 285-304.

[15] Gebel, Hans Georg K. 1993, Neolithic 'Ain Jamam near Ras an-Naqb: The Pre-1993 Field Research History, The Newsletter of Southwest Asian Neolithic Research.

[16] Glueck, N., 1934, "Explorations in eastern Palestine and Naqab, AASOR, 55, 3-12. 
[17] Glueck, N., 1937, “An aerial reconnaissance in southern Trans -Jordan” AASOR, 67, 19-29.

[18] Graf, D., 1979, "A preliminary report on a survey of Nabatean- Roman military sites in southern Jordan", ADAJ, 23, 121-127.

[19] Harahsheh, R, Waheeb, M, 2003, Nuqush Arabiyah Shamalyeh mn Ras Naqab, ADAD, 47, 25-32.

[20] Harding, L 2020, Journey to the Past, Pages of Lankester Harding, edited by Jihad Haroun \& Hala Syouf, Amman, Jordan.

[21] Jobling, W., 1981, "Preliminary report on the archaeological survey between Ma'an and Aqaba”, ADAJ, 25, 105-112.

[22] Kennedy, David; Banks, Rebecca (2015). "The Khatt Shebib in Jordan: From the Air and Space". Zeitschriftfür OrientArchäologie. 8: 132-154.

[23] Khasawneh, Sahar; Murray, Andrew; Abudanah, Fawzi (2019). "A first radiometric chronology for the KhattShebib megalithic structure in Jordan using the luminescence dating of rock surfaces". Quaternary Geochronology. 49: 205-210.

[24] Kirkbide, Alec, 1948, Khat Shabeeb in Transjordan, Antiquity, 151-154.

[25] Kirkbride, A, (September 1948). "Shebib's Wall in Trans Jordan" Antiquity. 22 (87): 151 -154.

[26] Kora, Mahmoud 1991 Litho stratigraphy of the early Paleozoic succession in Ras El-Naqabarea, east-central Sinai, Egypt.

[27] MacDonald, Burton (2015). The Southern Transjordan Edomite Plateau and the Dead Sea Rift Valley: the Bronze Age to the Islamic Period. Havertown: Oxbow Books. p. 174. ISBN 9781782978350 . OCLC 940437764.

[28] Macdonald, B Herr, L, Clark, G, Bradshaw, A, Corbett, J2005, The Ayl to Ras Anaqab Archaeological Survey, Phase 1, Preliminary Report, ADAJ-49, 277-298.

[29] Merrill, S, 1986, East of Jordan, London.

[30] Musil, A., 1926, The northern hegazczeh academy of science and arts, the American geographical society, New York.

[31] Oleson, J. P., 1986, "The Humayma hydraulic survey: preliminary Report of the 1986 season", ADAJ, 30, 253-260.

[32] Oleson, J. P., 1995, "The origins and design of Nabatean water -supply system" in SHAJ, vol. 5, 707-717.

[33] Peterson, A, 1991, Tow forts on the Medival Haj Route in Jordan, ADAD, 35, 347-359.
[34] Rollefson. G, 1999 Ayn Jammam and surrounding Stone Tools from 'Ayn Jammam, near Ras an-Naqb, Southern Jordan Department of Anthropology, Whitman College, Walla.

[35] Shami A, 1997, The Byzantine Settlement in Ras an-Naqab, Jordan University, Unpublished MA thesis, Dept. of Archaeology, Amman, Jordan.

[36] Southern Jordan. Tourist Jordan.(Arabic) Retrieved 2019-0606.

[37] Waheeb, M, 1994, Rasen Naqab Roads in Antiquity, unpublished report, Rasen Naqab Archaeological Project, 1994.

[38] Waheeb, M, 1996 "Archaeological Excavation at Ras an Naqab - 'Aqaba Road Alignment: Preliminary Report (1995), Annual of the Department of Antiquities of Jordan, 40, P.: 339-348.

[39] Waheeb, M, AbuDayyeh, A, 1997 "Recent Excavations at Ras an-Naqab", American Journal of Archaeology, Vol. 101/3., 501-502.

[40] Waheeb, M, 1997 A, Results of Field Excavations in Ras anNaqab, Report submitted to DAJ, DAJ Archives, 1997.

[41] Waheeb, M, 1997B “Ayen el - Jammam A Neolithic site Near Ras an- Naqab- southern Jordan, The prehistory of Jordan II: pp. 215-220.

[42] Waheeb, M,. \& Fino, N. 1997. 'Ayn el-Jammam: A Neolithic site near Rasel-Naqb, southern Jordan. In The Prehistory of Jordan II: Perspectives from 1997, ed.

[43] Waheeb, M, Doleh, Y 1999 "Uniza- Shobak Road Archaeological Survey", American Journal of Archaeology, Vol, 103/3, P.: 489.

[44] Waheeb, M, Zubi, Mahdi, 2007 New discoveries from Nabatean Age in Ras an-Naqab, Journal of Archaeologists Union, vol, 8, pp 43-59.

[45] Waheeb, M, 2010A, Quseir Shabeeb, AJA, 2010, 114, 3, 517518.

[46] Waheeb, M, Shawabkeh, Y, \&Khair, H, 2010B, The Discovery of Qaser Shabeeb, 1edition, Amman, Published by Ministry of Culture-Jordan.

[47] Waheeb, M, \& Khair, H2011, The discovery of Wadi Zarqa Civilizations, Zarqa, Al khat Al- Arabi Press, Jordan.

[48] Waheeb, M, 2012, The Discovery of Maan Civilizations, AlJafer, Amman, Published by Ministry of Culture -Jordan. 